
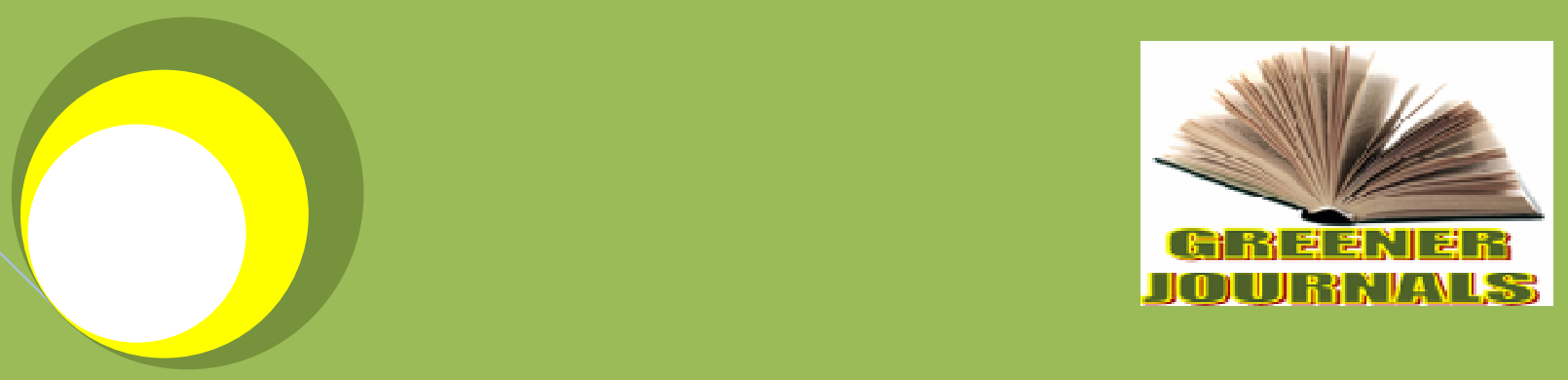

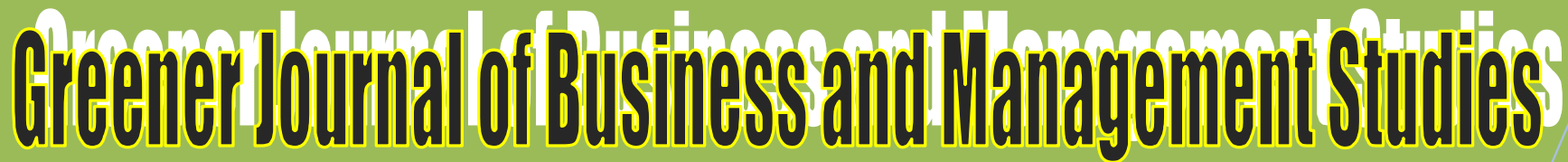
ISSN: 2276-7827 ICV: 6.02

Subject Area of Article: Agroeconomics

\title{
The Evaluation of Indonesia Import Policies of Garlic
}

By

Putra Aditama Hariwibowo

Ratya Anindita

Suhartini 


\title{
The Evaluation of Indonesia Import Policies of Garlic
}

\section{Putra Aditama Hariwibowo*1, Ratya Anindita ${ }^{2}$, Suhartini ${ }^{3}$}

\author{
${ }^{1}$ Master Student, Department of Social Economics, Faculty of Agriculture, University of Brawijaya. \\ ${ }^{2}$ Professor, Department of Social Economics, Faculty of Agriculture, University of Brawijaya. \\ ${ }^{3}$ Lecturer, Department of Social Economics, Faculty of Agriculture, University of Brawijaya.
}

*Corresponding Author's Email: hputraaditama@yahoo.com, Phone: (+62) 85748860253

\begin{abstract}
This study aims to analyze the factors that affect the supply, demand and price of garlic in Indonesia. In addition, also to seek alternative policies related to the import and production of garlic in Indonesia. Nerlove partial adjustment of supply and partial adjustment demand model are used in the estimation of supply and demand. The results showed that all the equations in the model are significant and qualified to statistical tests. In the short term, the entire exogenous variables are inelastic on its endogenous variables. But in the long term only garlic harvested area at one and two previous years, garlic productivity at one previous year, demand at one previous year and the import tariff that are elastic on its endogenous variables. Recommended alternative policies are the expansion of garlic farming land and continue to subsidize urea in addition provide protection against domestic garlic farmers through renegotiate the garlic import tariffs for long-term and maintain the stability of exchange rate in short term in order to create the conducive conditions of garlic market.
\end{abstract}

Keywords: garlic, supply, demand, price, import policies.

\section{INTRODUCTION}

Indonesia population growth continues to increase leading to increased demand for various agricultural commodities. In fact, the Indonesian agricultural commodity production is not sufficient the demand for the commodity that caused the deficit of supply. To cover this, the governments are extended the supply of agricultural commodities by importing those commodities from several countries. Indonesia as a country with many populations has become one of the main country for the purpose of international trade of agricultural products.

One of the agricultural commodities that rely on imports to meet the market demand is garlic. Garlic has a diverse role for the Indonesian people. Garlic bulbs are widely used as a seasoning in cooking because it has a fragrant aroma and distinctive taste. In addition, garlic is also used as a raw material for medicine because they contain substances like allium as a germ killer and antidote. Garlic caloric value is quite high, but the vitamin content is very low. It is use for herbs, only in small amounts. Other uses are not less important is the efficacy in the field of medicine, such as drugs for lowering high blood pressure, rheumatism, toothaches, snake bites contact, and others. In this regard needed to make garlic directly by the end user, start a small scale to the large household, restaurant / hotel, and industrial (Pramono et al, 2011).

The increasing number of Indonesian population and the smaller the value of production of garlic had been causing disequilibrium conditions in the domestic garlic market. Decreasing production of garlic among others caused by the lack of farmers' interest on garlic farming. The flood of imported garlic products which have low prices and great clove size is thought to be one factor that causes declining interest of farmers to cultivate garlic. Low productivity, among others, are also caused by the application of technical culture that has not been in accordance with the SOP (standard operating procedure) in the cultivation of garlic, also caused by the use of inferior quality seeds (Prastuti et al, 2011).Moreover, viral diseases also being responsible for the reduction of the bulbs sizes and consequently, low productivity. Garlic productivity in Indonesia just grow around $2.33 \%$ per year which caused by such condition. Moreover, the average of garlic harvested area's growth in last 30 years only $0.03 \%$ per year. This implies on the growth of garlic production in Indonesia which only $2.82 \%$ per year and shows decreasing trend in each year (FAO Statistics, 2013).

This condition is a major cause of the increase in the volume of imported garlic. Whereas in 1983, the import quantity of garlic just reach 9.92 thousand tons. Nowadays, that number reaches 439.91 thousand tons. Indonesia has heavily depends on imported garlic by $95 \%$ to fulfill national garlic demand (FAO Statistics, 2013). Garlic import surge to Indonesia started in 1986 when Indonesia government signed the Punta del Este as GATT system. That declaration resulted agricultural trade reform which required each country to convert their nontariff barriers into tariff and to decrease domestic and export subsidize for agriculture commodities. Other agreements on trade such as in region as well as multiregional also reinforce this policy such as AFTA, ACFTA and etcetera. 
So that the policies made by government was too focused on the import adjustment. Moreover, in practice, government does not set it up in a planned and well toward liberalization, so government is not free anymore in determining policies. That needed to be analyzed for the effects of policies that have been made against the supply, demand and price of garlic in Indonesia and then be a matter for policy evaluation that has been made by government. So in the future, some policies that able to accommodate the fulfillment the need of garlic for continuously and on the other hand also able to increase domestic production of garlic significantly, can be developed.

The purposes of this research among others: (a) analyze the factors that affect the supply, demand and price of garlic in Indonesia; (b) analyze the impact of government policies on import and production of garlic in Indonesia toward supply, demand and price of garlic in Indonesia; and (c) discover appropriate policy alternatives related to the import and production of garlic Indonesia.

\section{METHODOLOGY}

\section{Conceptual Framework}

The Increasing of Indonesia population caused increasing of garlic needs which implies on disequilibrium in garlic production and consumption cause excess demand in Indonesia garlic market which implies on import. The import garlic of Indonesia is showing no sign of decreasing trend while it production signs vice versa. This contradictive condition will continuously happens if government cannot observe the appropriate instrument for their policies to control garlic import and to increase domestic production of garlic. This instrument basically can obtain by analyzing the factors that affect supply, demand and price of garlic in Indonesia.

Supply of garlic is formed by it production and import. Import is affected by world and imported price of garlic, production, demand, tariff rates and exchange rate. The total production resulted from harvested area and productivity, which affected by several production factors and garlic price in farmer level. Meanwhile, demand of garlic affected by imported price of garlic, price of onion, income per capita, populations, and monetary crisis that occurred in 1997 until 1998. The price model such as imported and retail price of garlic constructed to see the behavior of price toward supply and demand of garlic in Indonesia.

Harvested area and garlic productivity equations constructed with Nerlove supply models. This model has been frequently used in supply response of agricultural products research, especially for crops like garlic. This is because farmers in growing crops not only based on the price of commodities at previous year, but rather on the expected price in current year (Nerlove, 1958). Similarly with the area of land to be planted, while the demand function using the Partial Adjustment Model (PAM). PAM has also been frequentlyusedindemand response of agriculturalproducts research, one of which is conducted by Adnyana (2013). The differencewiththe model usedin thatresearch isthe use of complementary commodity price variable (onion), notthe price ofsubstitutioncommodity. Then inthis research included a dummy variable to see the effect of financial crisison Indonesiagarlicdemand.For other functions such as import of garlic, Indonesia price of imported garlic and retail price of garlic are in form of static. The 2SLS method will used to analyze those models.

The estimation result of Indonesia economic model of garlic will produce factors that significantly influence the demand, supply andprice of garlic in Indonesia. These factors would be instruments informing alternative import policies of garlic. Production policy is included to see the effect of changes in garlic production quantity to changes in imports quantity. So that would be obtained an alternative policy that is capable of controlling imports. If import is controlled, it expected to stimulate domestic garlic farmers to plant garlic in order to significantly increase garlic production in Indonesia. 


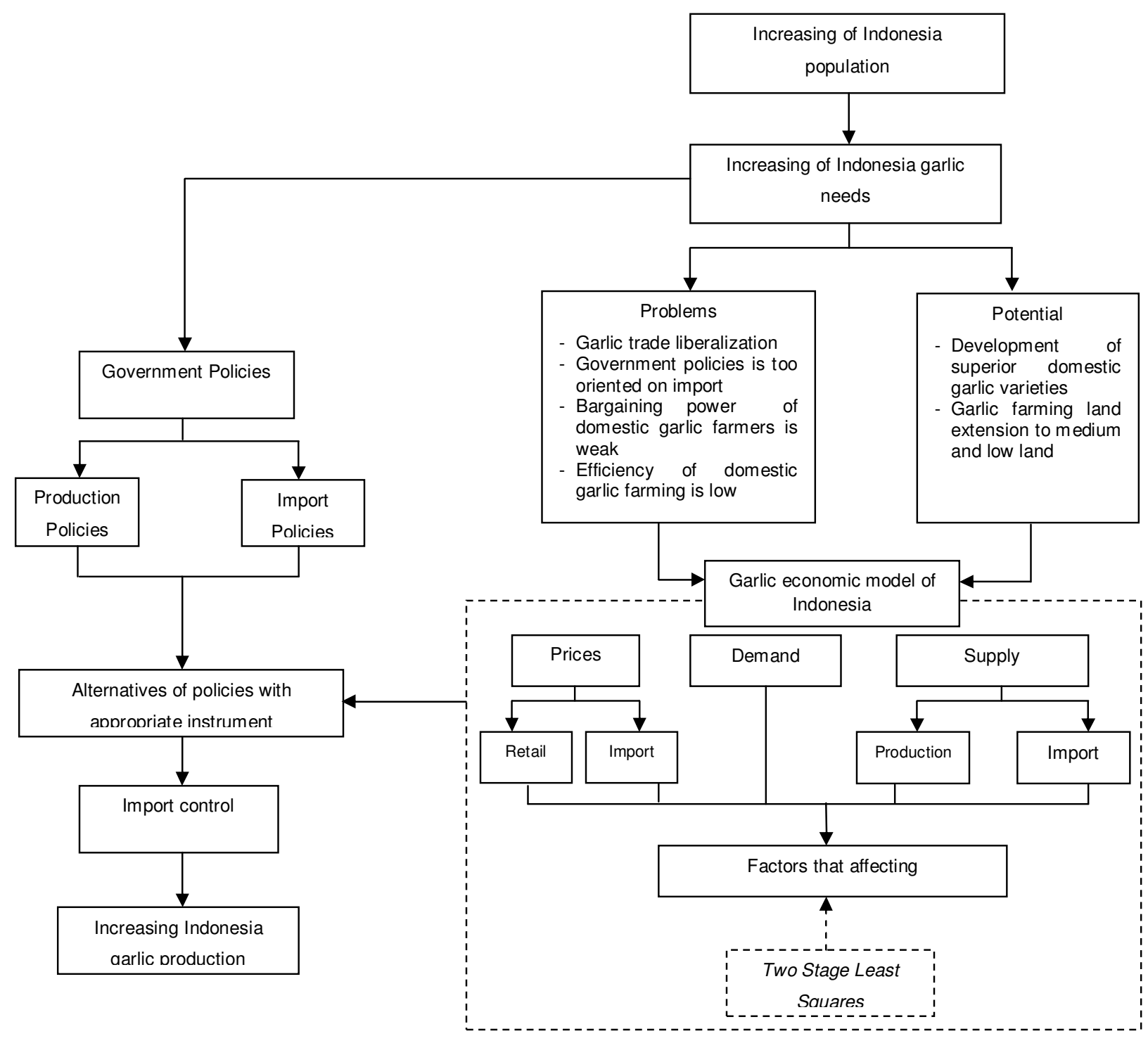

Figure 1. Conceptual framework of the Evaluation of Indonesia Import Policies of Garlic

\section{Empirical Model}

Garlic economic model in this study is divided into a supply, demand and price of garlic in Indonesia model which is mathematically described as follows.

\section{a. Supply Model}

The supply model inIndonesia garlic economic model consists of the following functions.

a. Indonesia Garlic Harvested Area

$I L a b_{t}=a_{0}+a_{1} I \operatorname{Pbpr}_{t-1}+a_{2} I L a b_{t-1}+a_{3} I L a b_{t-2}+a_{4} I P p u r_{t}+a_{5} I P p d r_{t}+a_{6} I C h j_{t}+a_{7} I \operatorname{Ppur}_{t-1}+a_{8} I P p d r_{t-1}+a_{9} I C j_{t-1}$

b. Garlic Productivity

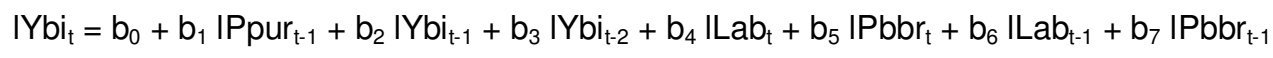

c. Indonesia Garlic Production 


$$
\mathrm{IQbi}_{\mathrm{t}}=\mathrm{ILab}_{\mathrm{t}}{ }^{*} \mathrm{IYbi} \mathrm{i}_{\mathrm{t}}
$$

d. Import of Garlic

$$
I M b p_{1}=c_{0}+c_{1} I P b w r_{t}+c_{2}\left|P b i r_{t}+c_{3}\right| Q b_{t}+c_{4} \mid Q d_{t}+c_{5} I T b_{t}+c_{6} I E r_{t}
$$

e. Indonesia Garlic Supply

$$
I Q s b_{t}=I Q b i_{t}+I M b p_{t}
$$

Where:

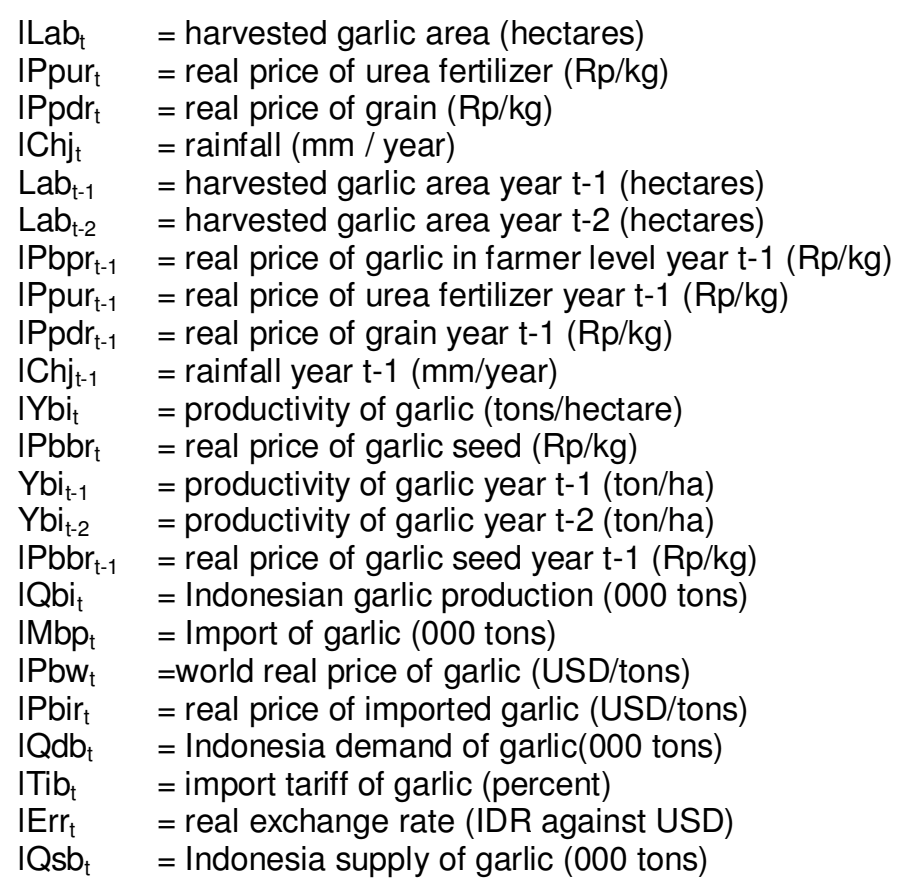

\section{b. Demand Model}

Demand model in Indonesia garlic economic model is mathematically described as follows.

a. Demand for Garlic in Indonesia

$I Q d b_{t}=d_{0}+d_{1} I P b i_{t}+d_{2} I P b m r_{t}+d_{3} I I p k_{t}+d_{4} I P o p_{t}+d_{5} D k m_{t}+d_{6} I Q d_{t-1}$

Where:

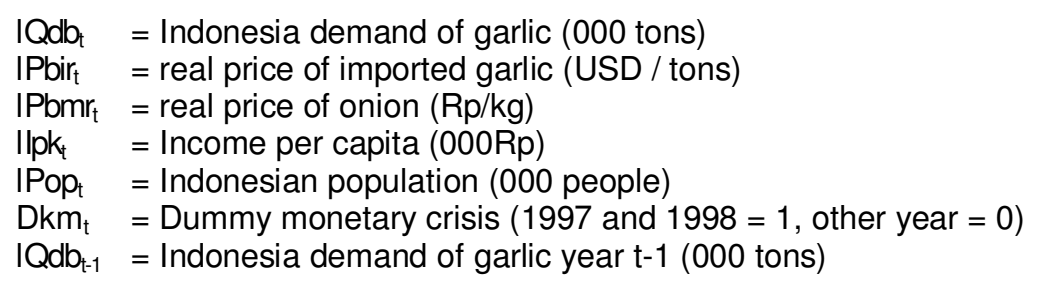

\section{c. Indonesia Garlic Price Model}

Indonesia garlic price model consists of the following functions.

a. Indonesia Price of Imported Garlic

$I P b r_{t}=e_{0}+e_{1}\left|P b r_{t}+e_{2}\right| T b_{t}+e_{3} \mid M b p_{t}$

b. Retail Price of Garlic 
IPber $_{t}=f_{0}+f_{1} I Q d b_{t}+f_{2} I Q s b_{t}+f_{3} I P b i r_{t}$

Where:

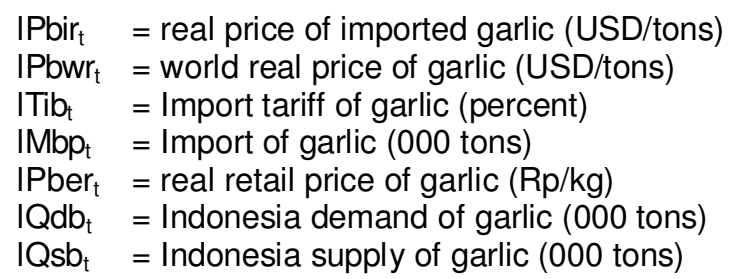

Identification of structural models is done based on order condition. The result shows that garlic economic model in this study is over identified. Prior to model estimation, stationarity and cointegration test is done to see whether there is any trend in the data element as well as to avoid the occurrence of a spurious estimation results. Stationarity test used Augmented Dickey Fuller Test (ADF Test) while Johansen method has used in cointegration test. Having seen the results obtained subsequent estimation of variance test results which include the F-test, $t$ test, and the coefficient of determination $\left(R^{2}\right)$. Test that used to see whether there is autocorrelation using the Durbin-h test which is calculated based on obtained Durbin Watson value.

Moreover, the value of short run and long run elasticity of each variable in the model also analyzed. The term of elasticity is used to obtain a response function of the quantity of other factors that influence it. Log models that used in this study make it possible to see the short-term elasticity value directly. If the model was in dynamic form, short-term and long-term elasticity can be calculated (Gujarati, 2004).

Validation of the model was conducted to determine whether recommended model is valid enough for policy simulation. Statistical criteria that used in validation of the model is Root Mean Square Error (RMSE), Root Mean Square Percent Error (RMSPE) and U-Theils inequality coefficient (U) (Pyndick and Rubinfeld, 1991). RMSE value is a measure of simulated values' deviation of endogenous variable on its actual value in percent. The smaller the value of RMSE, RMSPE, $U$, then the model can be said to be more valid for simulation. U component includes bias proportion (UM), proportion of variance (US) and proportion of covariance (UC).

If validation results fulfill the criteria of needed adequacy model validation, then policy simulations can be performed. Simulations were performed in this study were divided into pre-liberalization period (1983-1994) and post-liberalization period (1995-2013). Boundary between that two periods was in year 1994 when Indonesia signed a trade agreement with WTO (World Trade Organization) in April 1994.

Analysis of policy simulations in this study conducted in 10 scenarios namely:

\section{Pre Liberalization of Garlic Trade}

a. Changes in exchange rate against dollar (depreciation of $11 \%$ ).

b. Garlic import tariff policy (15\%).

c. Garlic import quota policy (quota $30 \%$ ).

d. Garlic farm land expansion $23 \%$.

e. Urea fertilizer subsidy $15 \%$.

\section{Post Liberalization of Garlic Trade}

a. Changes in the exchange rate against the dollar (10\% appreciation and $28 \%$ depreciation).

b. Garlic import tariff policy (zero tariff, $5 \%$ and $10 \%$ ).

c. Garlic Import quota policy (zero quota).

d. Garlic farm land expansion $17 \%$.

e. Urea fertilizer subsidy $10 \%$.

The last step is doing an evaluation of the policies that have been enacted by comparing the change between baseline value and simulated value of each endogenous variable. Evaluation is supported by previous research literature to be able to provide policy alternatives related to control garlic imports and increased production of garlic in Indonesia. 


\section{RESULT AND DISCUSSION}

\section{Data Description and Analysis}

This study uses yearly time series data from 1983 to 2013. The data such as garlic harvested area, garlic productivity, import of garlic, demand of garlic, world and imported price of garlic, and shallot price are obtained from Food and Agriculture Organization (FAO) Statistics. While data such as price of urea fertilizer, price of rice, price of garlic in farmer level, income per capita, population, and are obtained from Indonesia Central Bureau of Statistic. The other data such as garlic import tariff, exchange rate, and rainfall respectively are obtained from World Trade Organization (WTO), Indonesia Central Bank, and Indonesia Geophysics and Metrology Agency.

All price data such as world and imported price of garlic, shallot price, price of urea fertilizer, price of rice, price of garlic in farmer level, retail price of garlic and also exchange rate are deflated by producer and consumer price index. All of the variables converted into double logarithm form which allows see the value of the coefficient of elasticity parameters directly (Gujarati, 2004).

\section{Unit Root and Cointegration Test}

Prior to estimate Indonesian garlic economic model, first the stationarity and cointegration test are done to see trends in data element as well as to avoid spurious regression results. Stationarity test results by the method of Augmented Dickey Fuller test shows that real price variable grain (IPpdr), precipitation (IChj), Indonesia garlic productivity (IYbi), Indonesia garlic production (IQbi), garlic supply (IQsb), and income per capita (IIpk) stationary at level while the variables such harvested area of garlic (ILab), real price of garlic in farmer level (IPbpr), real price of urea fertilizer (IPpur), Indonesia import of garlic (IMbp), world real price of garlic (IPbwr), real price of Indonesia imported garlic (IPbir), Indonesia demand of garlic (IQdb), garlic import tariffs (ITib), real exchange rate (IErr), real price of onion (IPbmr), population (IPop ), monetary crisis dummy (Dkm), and real price of retail garlic (IPber) stationary at first difference level.The unit root test result shown at table 1.

Table 1. Unit Root Test Result

\begin{tabular}{|c|c|c|c|c|}
\hline \multirow[b]{2}{*}{ Variable } & \multirow{2}{*}{$\begin{array}{c}\text { Augmented } \\
\text { Dickey Fuller } \\
\text { (with intercept } \\
\text { and trend) }\end{array}$} & \multicolumn{3}{|c|}{ MacKinnon Critical Value } \\
\hline & & $1 \%$ & $5 \%$ & $10 \%$ \\
\hline \multicolumn{5}{|c|}{ Logarithm form (level) } \\
\hline IPpdr & -4.056104 & -3.679322 & -2.967767 & -2.622989 \\
\hline IChj & -4.863549 & -3.670170 & -2.963972 & -2.621007 \\
\hline IYbi & -4.133690 & -3.670170 & -2.963972 & -2.621007 \\
\hline IQbi & -4.993324 & -4.296729 & -3.568379 & -3.218382 \\
\hline IQsb & -7.418421 & -4.296729 & -3.568379 & -3.218382 \\
\hline IIpk & -6.824542 & -4.296729 & -3.568379 & -3.218382 \\
\hline ILab & -0.868936 & -4.339330 & -3.587527 & -3.229230 \\
\hline IPbpr & -3.142745 & -4.296729 & -3.568379 & -3.218382 \\
\hline IPpur & -1.347889 & -3.670170 & -2.963972 & -2.621007 \\
\hline IMbp & -2.707277 & -4.296729 & -3.568379 & -3.218382 \\
\hline IPbwr & -1.593726 & -4.296729 & -3.568379 & -3.218382 \\
\hline IPbir & -0.948511 & -4.296729 & -3.568379 & -3.218382 \\
\hline IQdb & -1.626715 & -4.296729 & -3.568379 & -3.218382 \\
\hline ITib & -2.362013 & -4.296729 & -3.568379 & -3.218382 \\
\hline IErr & -1.644138 & -4.296729 & -3.568379 & -3.218382 \\
\hline IPbmr & -3.096792 & -4.296729 & -3.568379 & -3.218382 \\
\hline IPop & -2.822328 & -4.309824 & -3.574244 & -3.221728 \\
\hline Dkm & -3.810857 & -4.309824 & -3.574244 & -3.221728 \\
\hline IPber & -2.841058 & -4.296729 & -3.568379 & -3.218382 \\
\hline \multicolumn{5}{|c|}{ Logarithm form (first difference) } \\
\hline IPpdr & -4.309824 & -4.205461 & -3.574244 & -3.221728 \\
\hline IChj & -6.353711 & -4.323979 & -3.580623 & -3.225334 \\
\hline IYbi & -6.269574 & -4.309824 & -3.574244 & -3.221728 \\
\hline IQbi & -5.988396 & -4.309824 & -3.574244 & -3.221728 \\
\hline IQsb & -9.813437 & -4.309824 & -3.574244 & -3.221728 \\
\hline IIpk & -5.781618 & -3.689194 & -2.971853 & -2.625121 \\
\hline ILab & -4.377086 & -3.679322 & -2.967767 & -2.622989 \\
\hline IPbpr & -7.087838 & -3.679322 & -2.967767 & -2.622989 \\
\hline
\end{tabular}




\begin{tabular}{ccccc}
\hline IPpur & -6.095002 & -2.647120 & -1.952910 & -1.610011 \\
\hline IMbp & -12.28429 & -4.309824 & -3.574244 & -3.221728 \\
\hline IPbwr & -6.079817 & -3.679322 & -2.967767 & -2.622989 \\
\hline IPbir & -3.871222 & -3.679322 & -2.967767 & -2.622989 \\
\hline IQdb & -5.685152 & -3.679322 & -2.967767 & -2.622989 \\
\hline ITib & -5.291503 & -2.647120 & -1.952910 & -1.610011 \\
\hline IErr & -4.815513 & -4.309824 & -3.574244 & -3.221728 \\
\hline IPbmr & -6.796195 & -3.679322 & -2.967767 & -2.622989 \\
\hline IPop & -4.125619 & -3.679322 & -2.967767 & -2.622989 \\
\hline Dkm & -6.123724 & -3.689194 & -2.971853 & -2.625121 \\
\hline IPber & -5.109552 & -2.647120 & -1.952910 & -1.610011 \\
\hline IPpdr & -4.056104 & -3.679322 & -2.967767 & -2.622989 \\
\hline IChj & -4.863549 & -3.670170 & -2.963972 & -2.621007 \\
\hline
\end{tabular}

Where:

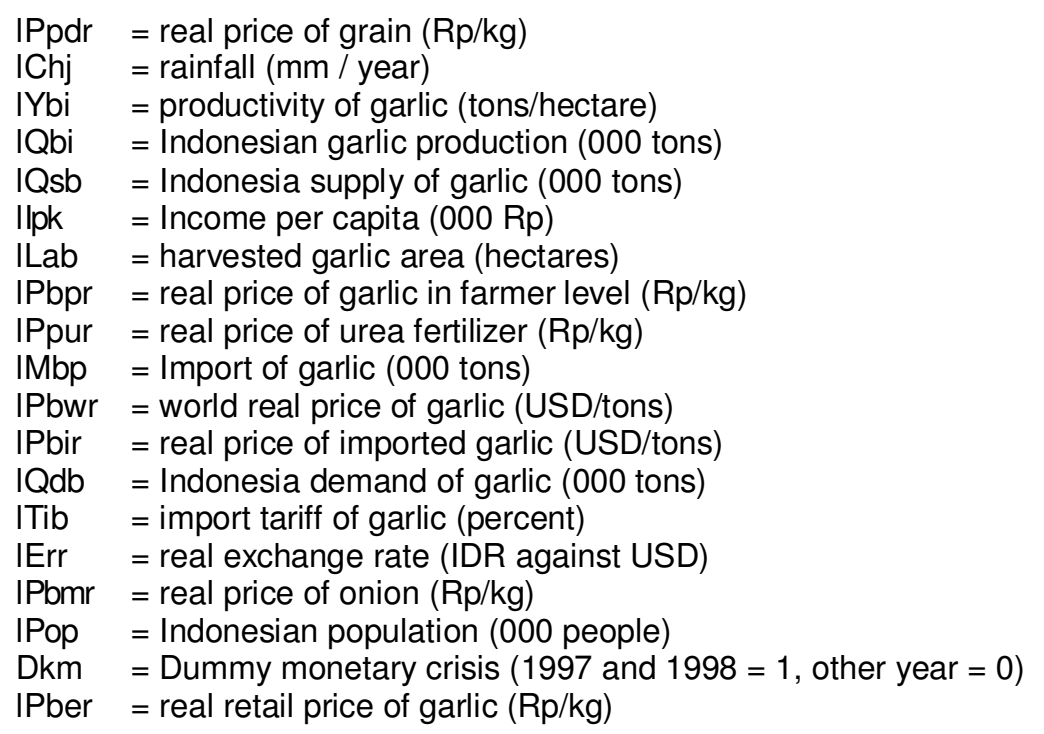

While the results of Johansen Julius cointegration test showed that all variables used in each model have greater trace and maximum eigen values than the critical value at $1 \%, 5 \%$ and $10 \%$ significance level. So that null hypothesis which states that there is no cointegration between the variables can be rejected, and the estimation result is avoided from spurious regression result. Table 5 to 10 shows the result of this test.

\section{Supply, Demand and Prices of Garlic in Indonesia}

The estimation result of entire equation in the model produce parameter coefficient also shows the value of elasticity. This is possible because the functional form of equation is in the double log. The results of 2SLS method estimation is to estimate short run models for equations like garlic harvested area, garlic productivity and Indonesia demand of garlic. Coefficient estimates for the model parameters obtained by obtaining long-term value of elasticity using short-term elasticity values that have been obtained previously. Meanwhile, for static models such import and prices are assumed to have met the form of long-term model. This estimation result shown in table 2. 
Table 2. Estimation Result of the Indonesia Garlic Economic Model

\begin{tabular}{|c|c|c|c|c|c|}
\hline \multirow[t]{2}{*}{ Significant Variables } & \multirow[t]{2}{*}{ Notation } & \multirow{2}{*}{$\begin{array}{c}\text { Coefficient } \\
\text { of } \\
\text { Parameters }\end{array}$} & \multicolumn{2}{|c|}{ Elasticity } & \multirow[t]{2}{*}{ Remarks } \\
\hline & & & Short Run & $\begin{array}{l}\text { Long } \\
\text { Run }\end{array}$ & \\
\hline $\begin{array}{l}\text { 1. Harvested Area } \\
\text { Lag of harvested area in year } t-1 \\
\text { Lag of harvested area in year } t-2 \\
\text { Rainfall } \\
\text { Lag of real price of urea in year } t- \\
1 \\
\text { Lag of real prices of grain in year } \\
t-1\end{array}$ & $\begin{array}{l}\text { ILab } \\
\text { Labl1 } \\
\text { Labl2 } \\
\text { IChj } \\
\text { Ppurl } \\
\text { Ppdrl }\end{array}$ & $\begin{array}{r}0.681310^{*} \\
0.297944^{\star * *} \\
-0.28668^{* *} \\
-0.00676^{* *} \\
0.003579^{\star * *}\end{array}$ & $\begin{array}{r}0.681310 \\
0.297944 \\
-0.28668 \\
-0.00676 \\
0.003579\end{array}$ & $\begin{array}{r}32.84055 \\
14.36152 \\
-13.8186 \\
-0.32585 \\
0.172515\end{array}$ & $\begin{array}{l}R^{2}=0.985 \\
\text { Adj } R^{2}=0.978 \\
F \text { hit }=139.27 \\
D h=1.8460 \\
\beta=1,00676 \\
Y=0,39113\end{array}$ \\
\hline $\begin{array}{l}2 \text { Garlic Productivity } \\
\text { Lag of garlic productivity in } \\
\text { yeart-1 }\end{array}$ & $\begin{array}{l}\text { IYbi } \\
\text { Ybil } 1\end{array}$ & $0.605656^{*}$ & 0.605656 & 1.595322 & $\begin{array}{l}R^{2}=0.490 \\
\text { Adj } R^{2}=0.379 \\
F \text { hit }=4.43 \\
D h=1.1684 \\
\beta=1,12801 \\
Y=0,266334\end{array}$ \\
\hline $\begin{array}{l}\text { 3. Import of Garlic } \\
\text { Indonesia garlic production } \\
\text { Import tariffs } \\
\text { Exchange rate }\end{array}$ & $\begin{array}{l}\text { IMbp } \\
\text { IQbi } \\
\text { ITib } \\
\text { IErr }\end{array}$ & $\begin{array}{l}0.482657^{\star *} \\
-15.8830^{\star} \\
0.006869^{\star}\end{array}$ & - & $\begin{array}{l}0.482657 \\
-15.8830 \\
0.006869\end{array}$ & $\begin{array}{l}R^{2}=0.959 \\
\text { Adj } R^{2}=0.947 \\
F \text { hit }=74.82 \\
D W=2.501306\end{array}$ \\
\hline $\begin{array}{l}\text { 4. Indonesia Demand of Garlic } \\
\text { real price of Indonesia imported } \\
\text { garlic } \\
\text { Lag of demand garlic Indonesia } \\
\text { in year t- } 1\end{array}$ & $\begin{array}{l}\text { IQdb } \\
\text { IPbir } \\
\text { Qdbl }\end{array}$ & $\begin{array}{l}-0.00262^{\star *} \\
0.900509^{\star}\end{array}$ & $\begin{array}{l}-0.00262 \\
0.900509\end{array}$ & $\begin{array}{l}-0.02633 \\
9.05116\end{array}$ & $\begin{array}{l}R^{2}=0.914 \\
\text { Adj } R^{2}=0.891 \\
F \text { hit }=40.65 \\
D h=-0.7021 \\
\alpha=0,09949\end{array}$ \\
\hline $\begin{array}{l}\text { 5. Garlic Import Price } \\
\text { Import tariffs }\end{array}$ & $\begin{array}{l}\text { IPbir } \\
\text { ITib }\end{array}$ & $814.6489^{*}$ & - & 814.6489 & $\begin{array}{l}\mathrm{R}^{2}=0.842 \\
\text { Adj } R^{2}=0.816 \\
F \text { hit }=33.23 \\
D W=1.9337\end{array}$ \\
\hline $\begin{array}{l}\text { 6. Garlic Retail Price } \\
\text { Indonesia demand of garlic } \\
\text { Indonesia supply of garlic } \\
\text { Indonesia real price of imported } \\
\text { garlic }\end{array}$ & $\begin{array}{l}\text { IPber } \\
\text { IQdb } \\
\text { IQsb } \\
\text { IPbir }\end{array}$ & $\begin{array}{l}-5.63815^{\star *} \\
-8.59036^{\star} \\
0.058165^{\star}\end{array}$ & - & $\begin{array}{l}-5.63815 \\
-8.59036 \\
0.058165 \\
\end{array}$ & $\begin{array}{l}R^{2}=0.974 \\
\text { Adj } R^{2}=0.969 \\
F \text { hit }=234.28 \\
D W=2.3413\end{array}$ \\
\hline
\end{tabular}

Source: Estimation Results, 2014

Note: $\left({ }^{*}\right)=$ significant at $5 \%$ level

$\left(^{* *}\right)=$ Significant at $10 \%$ level

$\left(^{\star \star \star}\right)=$ Significant at $15 \%$ level

The estimation results of economic model indicates that Indonesia harvested area of garlic positively affected by harvested area of garlic at one and two previous years and negatively affected by rainfall, real price of Urea at previous year, and real price of grain at previous year. All variables are inelastic in short run but harvested area of garlic at one and two previous years are elastic in long run. Partial adjustment coefficient value crop area response $(\beta)$ obtained at 1.00676 which means that farmers' response on adjustment of garlic harvested area is elastic. While the value of farmers' price expectations coefficient ( $\square$ ) obtained at 0.39113 which means that the proportion of farmers error between expected price of garlic with actual price of 0.3911 units or $39.11 \%$.

Garlic productivity is positively affected by garlic productivity at one previous year which inelastic in short run but elastic in long run. $\beta$ value obtained at 1.12801 which means the farmers' response on adjustment of garlic productivity is elastic. While the value of $\square$ obtained by 0.266334 which means that the proportion of farmers error between expected price of urea with actual price of 0.2663 units or $26.63 \%$.

Garlic Import is positively affected by Indonesian garlic production and exchange rates but negatively affected by import tariffs. All variables are inelastic in the long run. Indonesia demand of garlic is negatively affected by real price of Indonesia imported garlic and positively affected by Indonesia demand of garlic at one previous year. Only Indonesia demand of garlic at one previous year which is elastic in long run with response to adjusted value of garlic demand (a) is 0.099491 . 
The real price of Indonesia imported garlic is positively affected by import tariffs which is elastic in long run. While retail price of garlic is negatively affected by Indonesia garlic demand and Indonesia supply of garlic but positively affected by real price of Indonesia imported garlic. All variables are inelastic in long run. Overall, the exogenous variables that are elastic to its endogenous variables indicate that these variables would able to be right policy instrument for government in an effort to control the import and increase the production of garlic in Indonesia.

\section{Simulation Results of Indonesia Garlic Import Policies}

The results of pre liberalization policies simulation shows that policy of subsidizing fertilizer urea $15 \%$ resulted the largest increase in harvested area of garlic, but decreased productivity. Presumably there are other technical factors that affect. But generally provide the biggest change to production of garlic accompanied by a decrease in price of imported and retail garlic. Policy import tariffs of $15 \%$ obtain the largest decrease in imports which has implications for imported and retail garlic price hikes as well as a decrease in demand garlic.

While the results of post-liberalization period policies simulation shows that the policy of subsidizing fertilizer urea $10 \%$ had the greatest impact with the same implications as in pre-liberalization period. While the policy of import tariffs of $10 \%$ gives the same effect as the policy of import tariffs $15 \%$. Another policy which gives a similar effect is the $28 \%$ depreciation of exchange rate.

Table 3. Results of simulation of the pre liberalization policies

\begin{tabular}{llrrrrrr}
\hline \multirow{2}{*}{ Variables } & \multirow{2}{*}{ Unit } & \multirow{2}{*}{ Base Values } & \multicolumn{7}{c}{ Change (\%) } \\
\cline { 5 - 9 } & & & \multicolumn{1}{c}{ S1 } & \multicolumn{1}{c}{ S2 } & S3 & S4 & \multicolumn{1}{c}{ S5 } \\
\hline $\mathrm{ILab}$ & $\mathrm{Ha}$ & 14702.7983 & 0,000 & 0,000 & 0,000 & 18,666 & 20,233 \\
\hline $\mathrm{IYbi}$ & Tons/ha & 5.8857 & 0,000 & 0,000 & 0,000 & -6.820 & -2.364 \\
\hline $\mathrm{IQbi}$ & 000 tons & 113.2240 & 0,000 & 0,000 & 0,000 & 10,544 & 16,978 \\
\hline $\mathrm{IMbp}$ & 000 tons & 14.0670 & -26.886 & -241.552 & -1.550 & 22,357 & 34,741 \\
\hline $\mathrm{IQsb}$ & 000 tons & 150.9385 & -7.084 & -63.647 & -0.408 & 13,657 & 21,659 \\
\hline $\mathrm{IQdb}$ & 000 tons & 66.6346 & -12.195 & -84.839 & 0,000 & 0,000 & 0,000 \\
\hline $\mathrm{IPbir}$ & USD/Ton & 545.4000 & 3,557 & 25,064 & 0,000 & 0,000 & 0,000 \\
\hline $\mathrm{IPber}$ & USD/Kg & 4418.0000 & 4.120 & 33.952 & 0.136 & -4.980 & -7.334 \\
\hline
\end{tabular}

Source: Simulation Results, 2014

Where:

$\mathrm{ILab}=$ harvested garlic area (hectares)

IYbi = productivity of garlic (tons/hectare)

$\mathrm{IQbi}=$ Indonesian garlic production (000 tons)

$\mathrm{IMbp}=$ Import of garlic (000 tons)

IQsb = Indonesia supply of garlic (000 tons)

IQdb = Indonesia demand of garlic (000 tons)

IPbir = real price of imported garlic (USD/tons)

IPber $=$ real retail price of garlic $(\mathrm{Rp} / \mathrm{kg})$

$\mathrm{S} 1=11 \%$ depreciation of the rupiah against the dollar

S2 $=15 \%$ import tariffs

S3 $=30 \%$ import quota

S4 $=23 \%$ garlic farming land expansion

S5 $=15 \%$ urea fertilizer subsidy

Table 4. Results of the post-liberalization period the policy simulation

\begin{tabular}{|c|c|c|c|c|c|c|c|c|c|c|}
\hline \multirow{2}{*}{ Variables } & \multirow{2}{*}{ Unit } & \multirow{2}{*}{$\begin{array}{c}\text { Base } \\
\text { Values }\end{array}$} & \multicolumn{8}{|c|}{ Change (\%) } \\
\hline & & & S6 & S7 & S8 & S9 & S10 & S11 & S12 & $\mathrm{S} 13$ \\
\hline ILab & $\mathrm{Ha}$ & 14702.7983 & 0,000 & 0,000 & 0,000 & 0,000 & 0,000 & 0,000 & 17,274 & 27,449 \\
\hline IYbi & Tons/ha & 5.8857 & 0,000 & 0,000 & 0,000 & 0,000 & 0,000 & 0,000 & $\begin{array}{l}-5.522 \\
\end{array}$ & -5.094 \\
\hline IQbi & 000 tons & 113.2240 & 0,000 & 0,000 & 0,000 & 0,000 & 0,000 & 0,000 & 10,771 & 21,228 \\
\hline IMbp & 000 tons & 14.0670 & 12,587 & -35.240 & 22,793 & -49.514 & -121.818 & 2,164 & 10,270 & $\overline{19,803}$ \\
\hline IQsb & 000 tons & 150.9385 & 5,630 & -15.767 & 10,198 & -22.153 & -54.502 & 0.968 & 10,549 & 20,590 \\
\hline IQdb & 000 tons & 66.6346 & 9.571 & -26.800 & 16,604 & -26.348 & -69.303 & 0,000 & 0,000 & 0,000 \\
\hline IPbir & USD/Ton & 545.4000 & -3.553 & 9,906 & -4.702 & 11,557 & 27,837 & 0,000 & 0,000 & 0,000 \\
\hline IPber & USD/Kg & 4418.0000 & -5.480 & 15,355 & -10.147 & 18,231 & 46,609 & -0.543 & -5.751 & -10.743 \\
\hline
\end{tabular}


Where:

ILab = harvested garlic area (hectares)

$\mathrm{IYbi}=$ productivity of garlic (tons/hectare)

$\mathrm{IQbi}=$ Indonesian garlic production (000 tons)

IMbp = Import of garlic (000 tons)

IQsb = Indonesia supply of garlic (000 tons)

IQdb = Indonesia demand of garlic (000 tons)

IPbir = real price of imported garlic (USD/tons)

IPber $=$ real retail price of garlic $(\mathrm{Rp} / \mathrm{kg})$

S6 $=10 \%$ appreciation of the rupiah against the dollar

S7 $=28 \%$ depreciation of the rupiah against the dollar

S8 $=0 \%$ import tariff

S9 $=5 \%$ import tariff

$\mathrm{S} 10=10 \%$ import tariff

$\mathrm{S} 11=0 \%$ import quota

S12 $=17 \%$ garlic farming land expansion

S13 $=10 \%$ urea fertilizer subsidy

Table 5. Cointegration test result for garlic harvested area equation

Unrestricted Cointegration Rank Test (Trace)

\begin{tabular}{|c|c|c|c|c|}
\hline $\begin{array}{c}\text { Hypothesized } \\
\text { No. of CE(s) }\end{array}$ & Eigenvalue & $\begin{array}{l}\text { Trace } \\
\text { Statistic }\end{array}$ & $\begin{array}{c}0.1 \\
\text { Critical Value }\end{array}$ & Prob.** \\
\hline None * & 0.693943 & 101.3972 & 65.81970 & 0.0000 \\
\hline At most $1^{*}$ & 0.615690 & 67.06165 & 44.49359 & 0.0003 \\
\hline At most $2^{*}$ & 0.483592 & 39.32875 & 27.06695 & 0.0030 \\
\hline At most 3 * & 0.335342 & 20.16385 & 13.42878 & 0.0092 \\
\hline At most $4^{*}$ & 0.249355 & 8.317859 & 2.705545 & 0.0039 \\
\hline \multicolumn{5}{|c|}{ Unrestricted Cointegration Rank Test (Maximum Eigenvalue) } \\
\hline $\begin{array}{l}\text { Hypothesized } \\
\text { No. of CE(s) }\end{array}$ & Eigenvalue & $\begin{array}{l}\text { Max-Eigen } \\
\text { Statistic }\end{array}$ & $\begin{array}{l}0.1 \\
\text { Critical Value }\end{array}$ & Prob. ${ }^{* *}$ \\
\hline None * & 0.693943 & 34.33551 & 31.23922 & 0.0441 \\
\hline At most $1 *$ & 0.615690 & 27.73290 & 25.12408 & 0.0479 \\
\hline At most $2^{*}$ & 0.483592 & 19.16490 & 18.89282 & 0.0922 \\
\hline At most 3 & 0.335342 & 11.84599 & 12.29652 & 0.1166 \\
\hline At most 4 * & 0.249355 & 8.317859 & 2.705545 & 0.0039 \\
\hline
\end{tabular}

Table 6. Cointegration test result for garlic productivity equation

Unrestricted Cointegration Rank Test (Trace)

\begin{tabular}{ccccc}
\hline \hline $\begin{array}{c}\text { Hypothesized } \\
\text { No. of CE(s) }\end{array}$ & Eigenvalue & $\begin{array}{c}\text { Trace } \\
\text { Statistic }\end{array}$ & $\begin{array}{c}0.1 \\
\text { Critical Value }\end{array}$ & Prob.** $^{*}$ \\
\hline \hline None * & 0.668948 & 51.89747 & 27.06695 & 0.0000 \\
At most 1 * & 0.421931 & 19.83858 & 13.42878 & 0.0104 \\
At most 2 & 0.127180 & 3.944756 & 2.705545 & 0.0470 \\
\hline \hline Unrestricted Cointegration Rank Test (Maximum Eigenvalue) \\
\hline \hline Hypothesized & Migenvalue & Statistic & Critical Value & Prob. $^{* *}$ \\
No. of CE(s) & Eligen & \\
\hline \hline None * & 0.668948 & 32.05890 & 18.89282 & 0.0010 \\
At most 1 * & 0.421931 & 15.89382 & 12.29652 & 0.0274 \\
At most 2 * & 0.127180 & 3.944756 & 2.705545 & 0.0470 \\
\hline \hline
\end{tabular}


Table 7. Cointegration test result for import of garlic equation

Unrestricted Cointegration Rank Test (Trace)

\begin{tabular}{|c|c|c|c|c|}
\hline $\begin{array}{l}\text { Hypothesized } \\
\text { No. of CE(s) }\end{array}$ & Eigenvalue & $\begin{array}{l}\text { Trace } \\
\text { Statistic }\end{array}$ & $\begin{array}{c}0.1 \\
\text { Critical Value }\end{array}$ & Prob.** \\
\hline None * & 0.895484 & 201.1663 & 120.3673 & 0.0000 \\
\hline At most $1 *$ & 0.862449 & 135.6722 & 91.11028 & 0.0000 \\
\hline At most 2 * & 0.697291 & 78.14308 & 65.81970 & 0.0093 \\
\hline At most 3 & 0.479560 & 43.48853 & 44.49359 & 0.1211 \\
\hline At most 4 & 0.406852 & 24.54918 & 27.06695 & 0.1782 \\
\hline At most 5 & 0.201171 & 9.402170 & 13.42878 & 0.3295 \\
\hline At most 6 * & 0.094804 & 2.888518 & 2.705545 & 0.0892 \\
\hline \multicolumn{5}{|c|}{ Unrestricted Cointegration Rank Test (Maximum Eigenvalue) } \\
\hline $\begin{array}{l}\text { Hypothesized } \\
\text { No. of CE(s) }\end{array}$ & Eigenvalue & $\begin{array}{l}\text { Max-Eigen } \\
\text { Statistic }\end{array}$ & $\begin{array}{c}0.1 \\
\text { Critical Value }\end{array}$ & Prob.** \\
\hline None * & 0.895484 & 65.49414 & 43.29404 & 0.0002 \\
\hline At most $1^{*}$ & 0.862449 & 57.52909 & 37.27779 & 0.0002 \\
\hline At most 2 * & 0.697291 & 34.65455 & 31.23922 & 0.0403 \\
\hline At most 3 & 0.479560 & 18.93935 & 25.12408 & 0.4192 \\
\hline At most 4 & 0.406852 & 15.14701 & 18.89282 & 0.2787 \\
\hline At most 5 & 0.201171 & 6.513653 & 12.29652 & 0.5482 \\
\hline At most 6 * & 0.094804 & 2.888518 & 2.705545 & 0.0892 \\
\hline
\end{tabular}

Table 8. Cointegration test result for Indonesia demand for garlic equation

Unrestricted Cointegration Rank Test (Trace)

\begin{tabular}{|c|c|c|c|c|}
\hline $\begin{array}{l}\text { Hypothesized } \\
\text { No. of CE(s) }\end{array}$ & Eigenvalue & $\begin{array}{l}\text { Trace } \\
\text { Statistic }\end{array}$ & $\begin{array}{c}0.05 \\
\text { Critical Value }\end{array}$ & Prob. $^{* *}$ \\
\hline None * & 0.821445 & 120.3008 & 95.75366 & 0.0004 \\
\hline At most $1 *$ & 0.631865 & 70.33786 & 69.81889 & 0.0454 \\
\hline At most 2 & 0.496170 & 41.35800 & 47.85613 & 0.1775 \\
\hline At most 3 & 0.395546 & 21.47803 & 29.79707 & 0.3285 \\
\hline At most 4 & 0.182717 & 6.878567 & 15.49471 & 0.5918 \\
\hline At most 5 & 0.034802 & 1.027225 & 3.841466 & 0.3108 \\
\hline \multicolumn{5}{|c|}{ Unrestricted Cointegration Rank Test (Maximum Eigenvalue) } \\
\hline $\begin{array}{c}\text { Hypothesized } \\
\text { No. of CE(s) }\end{array}$ & Eigenvalue & $\begin{array}{l}\text { Max-Eigen } \\
\text { Statistic }\end{array}$ & $\begin{array}{c}0.05 \\
\text { Critical Value }\end{array}$ & Prob. ** \\
\hline None * & 0.821445 & 49.96292 & 40.07757 & 0.0028 \\
\hline At most 1 & 0.631865 & 28.97985 & 33.87687 & 0.1719 \\
\hline At most 2 & 0.496170 & 19.87998 & 27.58434 & 0.3495 \\
\hline At most 3 & 0.395546 & 14.59946 & 21.13162 & 0.3180 \\
\hline At most 4 & 0.182717 & 5.851342 & 14.26460 & 0.6324 \\
\hline At most 5 & 0.034802 & 1.027225 & 3.841466 & 0.3108 \\
\hline
\end{tabular}


Table 9. Cointegration test result for price of Indonesia imported garlic equation

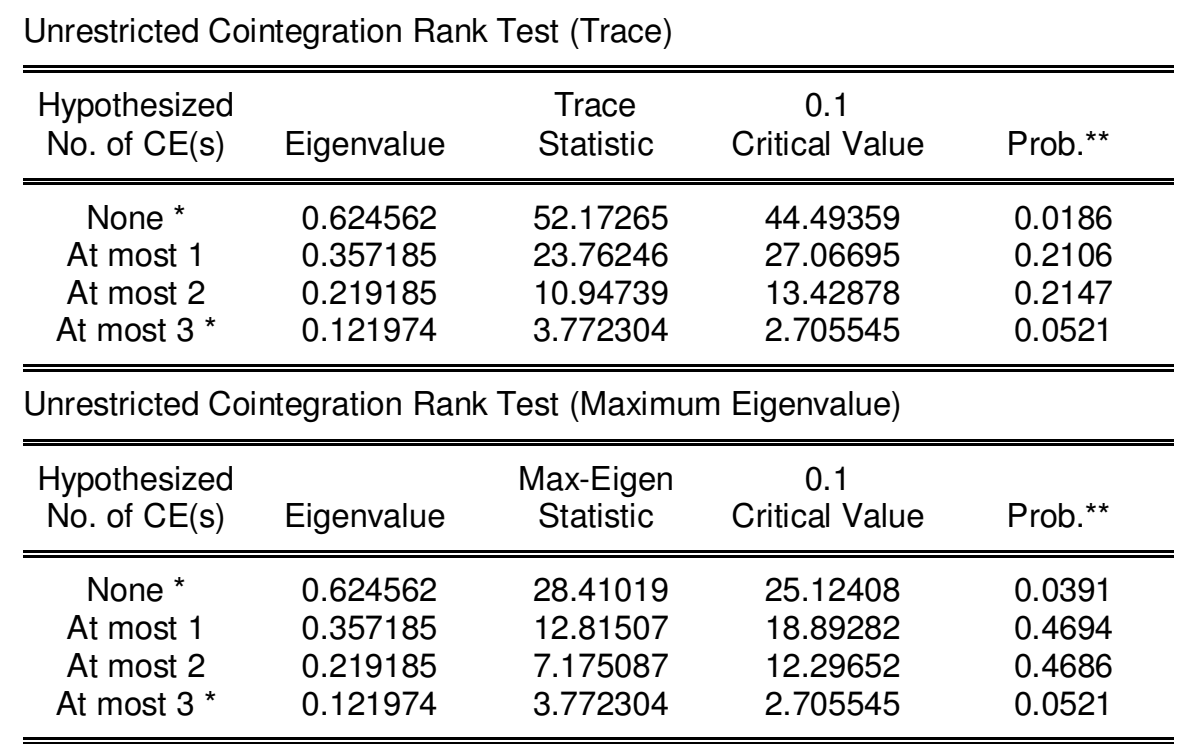

Table 10. Cointegration test result for retail price of garlic equation Unrestricted Cointegration Rank Test (Trace)

\begin{tabular}{|c|c|c|c|c|}
\hline $\begin{array}{c}\text { Hypothesized } \\
\text { No. of CE(s) }\end{array}$ & Eigenvalue & $\begin{array}{l}\text { Trace } \\
\text { Statistic }\end{array}$ & $\begin{array}{c}0.1 \\
\text { Critical Value }\end{array}$ & Prob.** \\
\hline None * & 0.613391 & 48.09293 & 44.49359 & 0.0475 \\
\hline At most 1 & 0.306505 & 20.53303 & 27.06695 & 0.3874 \\
\hline At most 2 & 0.211303 & 9.918696 & 13.42878 & 0.2870 \\
\hline At most 3 * & 0.099361 & 3.034865 & 2.705545 & 0.0815 \\
\hline \multicolumn{5}{|c|}{ Unrestricted Cointegration Rank Test (Maximum Eigenvalue) } \\
\hline $\begin{array}{l}\text { Hypothesized } \\
\text { No. of CE(s) }\end{array}$ & Eigenvalue & $\begin{array}{l}\text { Max-Eigen } \\
\text { Statistic }\end{array}$ & $\begin{array}{c}0.1 \\
\text { Critical Value }\end{array}$ & Prob.** \\
\hline None * & 0.613391 & 27.55990 & 25.12408 & 0.0504 \\
\hline At most 1 & 0.306505 & 10.61434 & 18.89282 & 0.6856 \\
\hline At most 2 & 0.211303 & 6.883831 & 12.29652 & 0.5030 \\
\hline At most 3 * & 0.099361 & 3.034865 & 2.705545 & 0.0815 \\
\hline
\end{tabular}

\section{Evaluation of Indonesia Import Policies of Garlic}

This evaluation is done by reviewing the results of policies simulation that has been done by government. For comparison, base value simulations are used to see any change in value of each endogenous variable in model. The results of policies simulations generally show that government should give greater attention on efforts to increase domestic garlic production instead of continually making changes to garlic import instrument. Efforts to increase production suggested not to completely eliminated import of garlic. Indonesia not eliminated imports because, in principle, the import of a commodity occurs because of three reasons as described by Tambunan (2008). First, the domestic production is limited while domestic demand is high (excess demand in the domestic market). So imports only as a supplement. Then the increase in domestic production will reduce imports. Limitations of the domestic production could be due to two things, namely: 
1. The production capacity is limited (the optimum point in the economies of scale have been achieved), for example, for the case of agriculture, the available land is limited because it is a small country; or

2. The use of the installed capacity is still below $100 \%$ due to various causes, could be because of limited funds or lack of manpower.

Second, imports are cheaper than the price of the product itself, which is due to various factors, such as highcost economy or a low level of efficiency in domestic production, or better quality imported products at a price that is relatively the same. So an increase in imports would reduce domestic production.

Moreover, should be no occurrence of negative changes to the policies that have been put in place so that farmers do not feel confused and cheated. If this occurs it is feared that it then makes farmers reluctant to plant garlic and chose to plant other more profitable commodities. Manumono et al (2009) warned of the challenges of a free market in the future. It makes businesses need to develop products capable of responding to market farming by offering competitive products. It is an opportunity and challenge for the government to give attention to horticultural subsector.

Refers to Irawan (2003), some concrete steps can be taken by government in order to increase Indonesia garlic production such as:

1. Build integrated agribusiness units in production center areas through involving garlic farmers, garlic production facilities retailer and garlic retailer.

2. Establish a cross horticultural production centers area agency.

3. Developing post harvest facilities in each unit of horticultural agribusiness.

Imposition of import quota policy is not recommended. This refers to the reality in the field where these policies actually lead to cartel practices. It encouraged cartel to manipulate the price of imports in order to meet the quota of imported garlic. Although import tariffs intended to increase government revenue does cause the opposite effect. Imposition of high tariffs without balanced with policies that support such import bureaucratic reforms would further complicate importers. Import tariff in addition basically intended to protect domestic producers also to increase government revenue (Kaempfer et al, 1985).

However, in the post-liberalization period as the current policy of import tariffs can no longer be applied even provide large welfare changes for producers and the government. The reason is the ACFTA agreement signed by Indonesia in 2005 where garlic import tariffs should be lowered to $0 \%$ or zero tariff. Indonesia is not hopeless. The government would be able to do a review of import tariffs for garlic commodity.

As per clause in the ACFTA, garlic included in Exception List, namely commodity groups still can be considered as related to the implementation of the tariff reduction in the sensitive and affect the economy of many people. The government since 2005 has sought to incorporate garlic in General Exceptions category, namely a certain commodity groups are not affected by the tariff reduction rules. But these efforts were deadlocked because of objection by Thailand.

Consider the imposition of import tariffs garlic requires a long time, so that alternatives can be applied for short-term as a protection for garlic farmer is to maintain the exchange rate against the dollar in lower real terms and keep the exchange rate movements are not too volatile. Mukhlis (2005), explains that the movement of the exchange rate volatility tends to only have positive impact on import demand for European countries (Germany, Italy, and Greece). As for Indonesia, it implied negative influence. If implemented, this policy has same effect with imposition of import tariffs.

Efforts of garlic farm land expansion and the provision by $23 \%$ and subsidy of $15 \%$ on Urea fertilizer should not be abandoned. The higher percentage will be much better. That is, besides the government should encourage farmer to increase domestic production of garlic should also provide protection for domestic garlic farmers. The Government through the Ministry of Agriculture basically already surveyed the medium plain in three regencies namely Majalengka, Magelang and Malang Regency by applying RRA method (Rapid Rural Appraisal).Moreover, trial planting garlic varieties in the lowlands has been conducted by the Research Institute Vegetable Crops (Balitsa), precisely in Yogyakarta using Lumbu Putih varieties.

Urea fertilizer subsidy policies belonging domestic support. Based on the Agreement on Agriculture (AoA) of the WTO, Urea fertilizer subsidy included in the Amber Box that is described as having an impact on the support of trade and production. If this policy is then questioned by the WTO and agreements participating countries, government subsidies can shift into the form of direct payments to farmers as compensation. Such policies included in the Blue Box. Urea fertilizer subsidy policy on the other hand need to be anticipated it negative impacts in domestic scale. Susila (2010) mentions the negative effects in the form of the dualism between subsidized fertilizer markets with non-subsidized fertilizer, excessive use of fertilizers by farmers, not optimal development of the fertilizer industry, which in turn lead to greater costs than benefits.

Government policies that have impact on the demand for garlic are actually not good for the national economy of Indonesia. Indonesia with a population exceeding 240 million is sustained by demand sector for it economic growth. Production sectors in Indonesia have not fully developed either Indonesian therefore often rely on imports to meet Indonesian needs. Thus the decrease in demand due to the increase in the price of commodities such as garlic can cause a decline in economic performance despite in partial term. 
Indonesian consumer awareness of the quality of the products makes them tend to promote quality in choosing horticultural products. Domestic garlic is a substitute commodity for imported garlic is not superior in terms of physical appearance. Imported garlic is known for its large size, attractive appearance because it is supported by good packaging and low prices. Domestic garlic is actually more superior in terms of aroma and freshness. Therefore, farmers are expected to see more dynamic consumer preferences due to the effects of globalization. Government programs such as the SL-PAH (Field School - Horticulture Agribusiness Development) and Project Garlic-Garlic Indonesian Revitalizing Agriculture by HORTIN are required to be run in long term according to the objective function and can improve the ability of garlic farmers in reading market opportunities and adapt their product quality with consumer preferences.

\section{CONCLUSION}

1. Harvested area of garlic is significantly affected by harvested area of garlic at one and two previous years, rainfall, real price of Urea at one previous year, and real price of grain one previous year. All variables are inelastic in short run but harvested area of garlic at one and two previous years are elastic in long run. Partial adjustment coefficient value crop area response ( $\beta$ ) obtained at 1.00676 which means that farmers' response on adjustment of garlic harvested area is elastic. While the value of farmers' price expectations of garlic coefficient $(\square)$ obtained at 0.39113 which means that the proportion of farmers error between the expected price of garlic with the actual price of 0.3911 units or $39.11 \%$.

2. Garlic productivity is significantly affected by garlic productivity at one previous year. It is inelastic in short run but elastic in long run. $\beta$ value obtained at 1.12801 which means the farmers' response to garlic productivity adjustment is elastic. While the value of $\square$ obtained by 0.266334 which means that the proportion of farmers error between the expected price of urea with the actual price of 0.2663 units or $26.63 \%$.

3. Import of garlic is significantly affected by Indonesia garlic production, import tariffs, and exchange rates. Entire variable is inelastic in long run. Indonesia still increase garlic import despite an increase in price of imported and world garlic and domestic production occur. This is because Indonesia has been dependent on imported garlic.

4. Indonesia demand of garlic is significantly affected by real price of Indonesia imported garlic and Indonesia demand of garlic at one previous year. Only Indonesia demand of garlic at one previous year which is elastic in long run with response to adjusted value of garlic demand (a) by 0.099491 .

5. The real price of Indonesia imported garlic is significantly affected by import tariffs which is elastic in long run. So that import tariff is a good instrument for policy concerning in controlling prices of Indonesia imported garlic.

6. Retail price of garlic is significantly affected by Indonesia demand of garlic, Indonesia supply of garlic and real price of Indonesia imported garlic. All variables have inelastic response on retail price of garlic so it is not a good instrument for policy in controlling retail prices of garlic.

7. Policies that can reduce import of garlic among others depreciation policy (11\% and $28 \%$ ), import tariffs (5\%, $10 \%$ and $15 \%$ ), import quota of $30 \%$, with no effect on the Indonesia garlic production. While $10 \%$ appreciation policies, elimination of tariffs and import quotas imply to increase imports of garlic with no effect on the production of garlic. Policy of garlic farming land expansion (23\% and $17 \%$ ), as well as providing subsidies urea (15\% and 10\%) were able to increase the Indonesia garlic production but imports also increased due to the production of garlic Indonesia has not contributed a lot in fulfilling the nationwide needs of garlic.

8. Recommended alternative policies such garlic farming land expansion and continue to subsidize urea fertilizer. Moreover, as a protection effort for domestic garlic farmers through renegotiating garlic import tariffs in long run while maintaining the stability of exchange rate in short run in order to create conducive condition of garlic market.

\section{RECOMMENDATION}

1. Further research related import of garlic is recommended to develop a model of harvested area and productivity by incorporating variables such as price of inputs production such as pesticides, seed prices as they become available, and wage of labor. So that it can be seen the effect of changes in these variables on the Indonesia garlic production.

2. The use of cross section data as accompany of time series data is recommended to be done because of the condition of each region in Indonesia which allows variation of data.

3. Garlic demand model is advised to be divided into two components, namely demand for household and industrial processing of garlic because garlic is almost always become the raw material in food processing industry. The benefit is to see the most crucial component in garlic demand levels. However the level of demand will determine the level of imported garlic in Indonesia. 
4. Indonesia government is suggested to re-evaluate or re-negotiate related reinstatement of import tariffs garlic. Imposition of import tariffs by 5 per cent can provide a big enough impact to change the overall welfare.

5. Government also suggested for establish floor and ceiling price for garlic. As an internal protection for Indonesia garlic producers and consumers. In the other hand, returning BULOG's monopoly ability on strategic agricultural commodities also possible to do if accompanying with comprehensive studies.

\section{COMPETING INTERESTS}

Authors have no competing interest to declare.

\section{AUTHORS' CONTRIBUTION}

All authors contributed to this work. Putra Aditama Hariwibowo participated in drafting the article, analysis data, interpretation of data, and also designed the manuscript. Ratya Anindita and Suhartini participated in revising critically for important intellectual content and gave final approval of the version to be submitted and any revised version.

\section{REFERENCES}

Adnyana MO, (2013). Penerapan Model Penyesuaian Parsial Nerlove Dalam Proyeksi Produksi dan Konsumsi Beras. Food Crops Research and Development Center: Bogor.

FAO Statistics, (2013). Garlic Productivity in Indonesia,http://www.fao.org. Accessed on April $5^{\text {th }} 2014$.

FAO Statistics, (2013). Garlic Harvested Area in Indonesia, http://www.fao.org. Accessed on April $5^{\text {th }} 2014$.

FAO Statistics, (2013). Import of Garlic in Indonesia, http://www.fao.org. Accessed on April $5^{\text {th }} 2014$.

Gujarati DN, (2004). Basic Econometrics . Third Edition. Mc Graw-Hill, Inc., New York.

Kaempfer WH et al, (1995). International Trade Theory and Evidence. Mc Graw Hill Inc: New York.

Koutsiyannis A, (1977). Theory of Econometrics . Second Edition. The Macmillan Press Ltd., London.

Intriligator MD (1978). Econometric Models : Techniques, and Applications. Prentice-Hall Inc: New Jersey.

Irawan B, (2003). Agribisnis Hortikultura: Peluang dan Tantangan Dalam Era Perdagangan Bebas. Agricultural Socioeconomics Research and Development Center: Bogor.

Manumono D, dkk. (2009). Trade Off Sistem Usahatani Tembakau di Wilayah Sumbing Temanggung Jawa Tengah. J-SEP Vol. 3 No. 3 Nopember 2009.

Mukhlis I, (2011). Analisis Volatilitas Nilai Tukar Mata Uang Rupiah Terhadap Dollar. Journal of Indonesian Applied Economics Vol. 5 No. 2.

Nerlove ML (1956). Estimates of the Elasticities of Supply of Selected Agricultural Commodities. Journal of Farm Economics Vol 38 No. 2.

Nerlove ML, (1958). The Dynamics of Supply: Estimation of Farmers Response Top Prices. The John Hopkins Press: Baltimore.

Pyndick RS and DL Rubinfeld, (1991). Econometric Models and Economic Forecasting . Third Edition. Mc GrewHill International: Singapore.

Pramono J Samijan and TR Prastuti, (2011). Usaha Perbenihan Bawang Putih di Lahan Kering Dataran Tinggi Kabupaten Tegalin Risalah Hasil Pengkajian Inovasi Hortikultura di Jawa Tengah p.52-61. Agriculture Technology Studies Agency: Central Java.

Prastuti TR Samijan and J Pramono, (2011). Intensifikasi Budidaya Bawang Putihin Risalah Hasil Pengkajian Inovasi Hortikultura di Jawa Tengahp.62-81. Bureau of Agriculture Technology Study: Central Java.

Tambunan, T, (2008). Ketahanan Pangan di Indonesia, Mengidentifikasi Beberapa Penyebab. Pusat Studi Industri dan UKM Universitas Trisakti: Jakarta.

Cite this Article: Putra AH, Ratya A, Suhartini, 2015. The Evaluation of Indonesia Import Policies of Garlic, Nigeria. Greener Journal of Business and Management Studies, 5(1):016-030, http://doi.org/10.15580/GJBMS.2015.1.081414329. 